\title{
Distribution of Different Forms of Potassium in Relation to Soil Properties in Agricultural Entisols of Terai Region of West Bengal, India
}

\author{
N.K. Singh, G.C. Banik* and D. Mukhopadhyay
}

Department of Soil Science and Agricultural Chemistry, Faculty of Agriculture, Uttar Banga Krishi Viswavidyalaya, Pundibari, Cooch Behar, West Bengal-736165, India

*Corresponding author

\section{A B S T R A C T}

\section{Keywords}

Forms of potassium, Available K,

Exchangeable K, Soil properties

Article Info

Accepted:

10 November 2019

Available Online:

10 December 2019
Surface (0-20) and sub-surface (20-40) soils from six different administrative blocks (Dhuluabari, Pundibari, Toofanganj, Mathabhanga, Dinhata and Sitai) of Cooch Behar district of West Bengal situated in terai region of Himalayan flood plain, India were analyzed to characterize the spatial distribution of different forms of potassium $(\mathrm{K})$. The soils were acidic in nature, mostly sandy loam in texture and variable in organic carbon content and CEC. The corresponding distribution of $\mathrm{K}$ forms did not much varied in soils of different blocks in both the layers. The total $\mathrm{K}$ and constituently structural $\mathrm{K}$ were found higher in Dinhata surface soils as compared to other soils. However, available $\mathrm{K}$ was more in Toofanganj surface soils followed by Mathabhanga surface soils. All the $\mathrm{K}$ fractions were much lower in sub-surface layer than surface layer may due to the lower organic carbon, clay and CEC as they exhibited significant positive correlation with different forms of $\mathrm{K}$. Predictability of $\mathrm{K}$ forms was much dependent of soil properties, mostly on organic carbon, clay and CEC.

\section{Introduction}

Continuous following of high yielding exhustive rice-based cropping systems in India caused mining of soil nutrients far in excess of external nutrients inputs in forms of fertlizer resulting in negatve nutrient balance in soil. According to the Department of Fertlizers, Ministry of Agriculture, Government of India the farmers supply imbalanced doses of major fertlizers in soil. The NPK use ratio in the country depleted fron 5.5:2.1:1 in 2007-08 to 6.7:3.1:1 in 2011-12 which much differ from the believed ideal ration of $4: 2: 1$. It is known that the crops removes potassium $(\mathrm{K})$ about three to four times of the phosphorus removal and is equal to that of nitrogen from soil. Hence continuous cropping with imbalanced 
fertlization may lead to substantial depletion of reserve potassiuum in soil which would go unnoticed as per the conventional soil test i.e., available-K (Sanyal, 2001). The lower use of potassium in soil leading to much drawal of inherent potassium reserve from soil is mainly due to the reluctance of farmers to use $\mathrm{K}$ fertlizers, presumably on the common belief that the soils of West Bengal are rich in potash (Sarkar et al., 2013). Such depletion of potassium gives us a omnious sign that if the strategies and policies are not formulate to boost the $\mathrm{K}$ supply in soil, and this essential nutrient remains neglected as in past, the future sustainibility of agriculture is likely to be constrained.

Based on degree of availability to crops, soil potassium $(\mathrm{K})$ can be partitioned into four forms, namely water soluble $\mathrm{K}$, exchangeable $\mathrm{K}$, non-exchangeable $\mathrm{K}$ and structural $\mathrm{K}$ which are in dynamic equilibrium with each other (Tijjani and David, 2017).Water soluble $\mathrm{K}\left(\mathrm{K}_{\mathrm{ws}}\right)$ is usually considered the primary source of $\mathrm{K}$ absorbed by plant roots; exchangeable $\mathrm{K}\left(\mathrm{K}_{\mathrm{ex}}\right)$ is held by the negative charges on soil clay and organic matter exchange sites. Non-exchangeable K (NEK) $\left(\mathrm{K}_{\text {nex }}\right)$ is held as fixed ions in the lattice structure of clay minerals and that forms part of the structures of minerals. Structural $\mathrm{K}\left(\mathrm{K}_{\mathrm{s}}\right)$ is found in $\mathrm{K}$ bearing minerals in soils depending primarily on the source of the parent material (Rao and Brar, 2002). Conversion of structural $\mathrm{K}$ to nonexchangeable form is very slow and it varies with type of clay mineral and its condition of weathering. Further, the contribution of structural $\mathrm{K}$ to crop nutrition through decomposition and re-synthesis process is extremely low and negligible in a single crop growing season. Therefore, it is obvious that $\mathrm{K}$ supply to plant from soil is a complex phenomenon, involving a dynamic equilibrium amongst its various chemical forms in soil. The first two forms of soil $\mathrm{K}$ are considered to be labile and meet the immediate requirements of growing plants, while the last two are considered non-labile and are responsible for the long-term supply of $\mathrm{K}$ to plants (Askegaard et al., 2003).

The different forms of soil potassium are in dynamic equilibrium (as stated earlier) and any depletion in a given $\mathrm{K}$ form is likely to shift equilibrium in the direction to replenish it (Ramamoorthy and Paliwal, 1976). The K status in soil and the potential of K supply to plant is very much related with the distribution of $\mathrm{K}$ forms in the soil and the equilibrium between them (Pavlov, 2007) which is again influenced by the various physical, chemical, properties such as clay minerals, texture, moisture, cation exchange capacity (CEC), $\mathrm{pH}$, concentrations of other ions (Lalitha and Dhakshinamoorthy, 2014).

The soils of terai region of West Bengal is of recent origin (alluvium) and is derived from deposition of erosion products brought and laid down by various river systems from Himalayas. The dominant soil order is Entisol. The topsoil, in general, is shallow (0.2 $1.5 \mathrm{~m})$ with the basic rock formation of igneous and/or metamorphic in origin. The average annual rainfall in this region is about more than $3000 \mathrm{~mm}$. For a critical appraisal of potassium supplying capacity of soils, knowledge of different forms of potassium and conditions controlling their availability is essential. Though adequate information is available on the forms of potassium and its availability in the soils of adjoining state of Assam (Basumatary and Bordoloi 1992) very little is known about this nutrient in the soils of Cooch Behar of West Bengal.

On such background the present study was designed to ascertain distribution of different forms of potassium in selected soils of Cooch Behar district situated at terai region of West Bengal and their relation with soil properties. 


\section{Materials and Methods}

\section{Soil sampling and characterization}

Soil samples for the present investigation were collected from two soil depths, surface soil (0$20 \mathrm{~cm})$ and sub-surface soil $(20-40 \mathrm{~cm})$, from farmers' fields of six different blocks of Cooch Behar district of West Bengal, namely, Cooch Behar-I (Dhuluabari), Cooch behar-II (Pundibari), Toofanganj-I, Mathabhanga-I, Dinhata-I and Sitai. The lower depth soils were excluded because of the high sand and less clay content. The collected soils from different points of each location were composited in a single sample. Each soil sample was gently broken down by hand, being careful not to unnecessarily tear the plant roots, then air-dried at $35^{\circ} \mathrm{C}$ to constant weight in the laboratory. The soil samples were then passed through a 2-mm brass sieve. The samples were then kept in laboratory in paper bags with proper label for further analysis. The important physico-chemical properties of these soils $(\mathrm{pH}$, EC. organic carbon, particle size distribution, CEC etc.) were determined by following methods described by Jackson (1973).

\section{Determination of different forms of potassium}

The water soluble $\mathrm{K}$ was measured by the method proposed by Grewal and Kanwar (1966) by using the soil: water ratio of 1:5. The available $\mathrm{K}$ was determined by neutral normal $\mathrm{NH}_{4} \mathrm{OAc}$ extractant in the ratio of 1:10 (soil: extractant) as outlined by Pratt (1965). Exchangeable potassium was obtained from the difference between available and water soluble potassium (Dhillon et al., 1985). Nonexchangeable $\mathrm{K}$ was determined by one time extraction of soil with boiling $1 \mathrm{M} \mathrm{HNO}_{3}$ (Pratt, 1965). In this method, the soil and the acid suspension (1:10 ratio) were allowed to boil gently for 10 minutes over sand bath. The
$\mathrm{K}$ extracted in this method minus $\mathrm{K}$ extracted by neutral normal Ammonium acetate (available K) gave the non-exchangeable $\mathrm{K}$ of the soil. Total $\mathrm{K}$ in soils was determined most conveniently by wet digestion of the soil sample with hydrofluoric acid (HF) and perchloric acid $\left(\mathrm{HClO}_{4}\right)$ as described by Pratt (1965). For total $\mathrm{K}$ determination $0.1 \mathrm{~g}$. of finely ground soil sample (dried at $100^{\circ} \mathrm{C}$ for 2 hours) was placed in $30 \mathrm{ml}$ platinum $(\mathrm{Pt})$ crucible moistened with few drops (1-2 drops) of distilled water. After that $5 \mathrm{ml} \mathrm{HF} \mathrm{(48 \% )}$ and $0.5 \mathrm{ml} \mathrm{HClO}_{4}(60 \%)$ were added into it. The crucible was then put on a sand bath, and nine-tenths of the crucible top was covered with a platinum lid. The crucible was then heated to $200-225^{\circ} \mathrm{C}$ until the acid evaporates to dryness. The content was cooled and $5 \mathrm{ml}$ of distilled water and a few drops of $\mathrm{HClO}_{4}$ were added into it. The crucible was heated again to boil the content which was evaporated to dryness. The crucible content was again cooled and $5 \mathrm{ml}$ of $6 \mathrm{M} \mathrm{HCl}$ was added and diluted it to $2 /{ }_{3}$ rd of crucible volume. The content was allowed to boil gently until the residue was completely dissolved in acid solution. The suspension was cooled, transferred to $100 \mathrm{ml}$ volumetric flask, volume was making up and the $\mathrm{K}$ content in the solution was determined by a flame photometer (Model: Systronics 128, Systronics, India).

\section{Statistical calculation}

Pearson correlation coefficient and step-down multiple regression equations were generated using Microsoft office excel 2016.

\section{Results and Discussion}

\section{Soil characterization}

The soils were acidic in reaction with the $\mathrm{pH}$ value ranged between5.49-6.38 and 5.58-6.49 for surface and subsurface soils, respectively 
(Table 1). The electrical conductivity in both surface and sub-surface soils was low, i.e., ranged from 0.05-0.08 and 0.034-0.07 $\mathrm{dSm}^{-1}$, respectively. Thus, the salt content of these soils is considered safe for the crop production. The EC values were in general lower in the sub-surface soils than the surface soils. The mean organic carbon content was much lower in the sub-surface $(0.248 \%)$ soils than the surface soils $(0.75 \%)$. This may be due to the accumulation of organic matter in the surface soils. The textural classes of all the soil samples were of sandy loam. The cation exchange capacity (CEC) in the surface soils was higher than the sub-surface soils. The CEC of these soils were low ranged between 2.05-6.5 $\mathrm{cmol}\left(\mathrm{p}^{+}\right) \mathrm{kg}^{-1}$.

\section{Distribution of different forms of potassium in soil}

The water soluble $\mathrm{K}\left(\mathrm{K}_{\mathrm{ws}}\right)$ in the experimental soils ranged from 0.037 to $0.109 \mathrm{cmol}^{+} \mathrm{kg}^{-1}$ (Table 2) including both surface and subsurface zones. The sub-surface soil exhibited little lower amount of water soluble $\mathrm{K}$. The $\mathrm{K}_{\mathrm{ws}}$ contributed only the $0.089-0.205 \%$ towards total potassium of soil. This amount seemed to be quite inadequate to meet the immediate $\mathrm{K}$ requirement particularly for the short duration crops (Saini and Grewal, 2014). The correlation studies as presented in table 3 showed that the $\mathrm{K}_{\mathrm{ws}}$ was positively correlated with $\mathrm{pH}(\mathrm{r}=0.232)$, EC $(\mathrm{r}=0.439)$, organic carbon $\left(\mathrm{r}=0.680^{*}\right)$, clay $\left(\mathrm{r}=0.687^{*}\right)$ and CEC $(r=0.694 *)$ of the soil. The significant positive correlation with organic carbon content may be partly due to the release of labile K from organic residues (Singh and Tripathi, 1993) and also to the capacity of organic carbon in blocking specific and nonspecific K-binding sites, thus reducing Kfixation (Singh et al., 1998). Its negative correlation $(r=-0.574)$ with sand content may be attributed to the less CEC of sand. It had the significant positive correlations with other forms of $\mathrm{K}$ (Table 3). Multiple regression equations as given in table 4 indicate the contribution of different soil properties to predict the availability of different forms of potassium. It was noticed that the $\mathrm{K}_{\mathrm{ws}}$ predictability was $86.58 \%$ when all the factors were taken together, but it decreased $21.38 \%$ when only $\mathrm{pH}$ and EC were considered. The inclusion of organic carbon increased the predictability to $71.01 \%$ over $\mathrm{pH}$ and EC.

The exchangeable potassium $\left(\mathrm{K}_{\mathrm{ex}}\right)$ of soil ranged between $0.193-0.446 \mathrm{cmol}^{+} \mathrm{kg}^{-1}$ and 0.106- $0.228 \mathrm{cmol}^{+} \mathrm{kg}^{-1}$ in surface and subsurface soils, respectively thus showing the lower $\mathrm{K}_{\mathrm{ex}}$ in sub-surface soil. Considering 157 $\mathrm{kg} \mathrm{ha}^{-1}$ of $\mathrm{K}_{\mathrm{ex}}$ as the lower limit of sufficiency (Bray, 1948), it was adequate in the surface zone of soils under study. The $\mathrm{K}_{\mathrm{ex}}$ constituted 0.224 to $0.637 \%$ of total $\mathrm{K}$ considering both the layers as single zone. Reza et al., (2014) also made similar observation for soils of lesser Himalayas of Sikkim adjacent to the terai region of West Bengal. The $\mathrm{K}_{\mathrm{ex}}$ showed a significant close relationship with the content of clay $\left(\mathrm{r}=0.745^{* *}\right)$ and organic matter $(0.682 *)$ in these soils (Table 3$)$. These positive correlations presumably support the presence of potassium containing electrostatic outer-sphere complex to the surface of clay minerals and humic substances present in soil (Spark, 2000). Thus, a sizable fraction of $\mathrm{K}_{\mathrm{ex}}$ may remain adsorbed on the exchange sites of organic carbon (Singh and Datta, 1986). $\mathrm{K}_{\mathrm{ex}}$ was negatively correlated with sand content of soil $\left(\mathrm{r}=-0.735^{* *}\right)$, this may be due to less content of potassium bearing minerals in sand fractions (Das et al., 2000) as well as lack of surface charges on sand grains and lower CEC. The $\mathrm{K}_{\mathrm{ex}}$ exhibited positive correlations with all other forms of $\mathrm{K}$ present in soil as well. There was much variation (52.52 to $63.58 \%$ ) upon inclusion of clay on predictability of $\mathrm{K}_{\mathrm{ex}}$ over $\mathrm{pH}$, EC, Organic carbon, sand and silt. Much variability (30.34$49.22 \%$ ) observed on inclusion of organic carbon over $\mathrm{pH}$ and EC (Table 4) may be due to the positive correlation of $\mathrm{K}_{\mathrm{ex}}$ and organic 
carbon $(\mathrm{r}=0.682 *)$ (Table 3). The plant available potassium $\left(\mathrm{K}_{\mathrm{ws}}+\mathrm{K}_{\mathrm{ex}}\right)$ was higher in Toofanganj and Mathabhanga surface soils than in other soils. The available $\mathrm{K}$ constituted $0.351-0.923 \%$ of total potassium. Significantly positive correlations observed with organic carbon $\left(\mathrm{r}=0.764^{* *}\right)$, clay $\left(\mathrm{r}=0.824^{* *}\right)$ and CEC ( $\mathrm{r}=0.742 * *)$ suggests its dependence on organic matter and clay content of soil (Singh et al., 1998; Bashir et al., 2016). Variability of available $\mathrm{K}$ also increased much (68.07$74.07 \%$ ) upon addition of clay content over $\mathrm{pH}, \mathrm{EC}$, Organic carbon, sand and silt (Table 4). The variability of available $K$ could be explained by $75.07 \%$ taking all the factors together. However, it decreased to $68.07 \%$ on exclusion of clay and CEC.

The non-exchangeable $\mathrm{K}\left(\mathrm{K}_{\text {nex }}\right)$ or reserve $\mathrm{K}$ being an index of $\mathrm{K}$ availability under stress situation (K-depleted condition may due to the exhaustive cropping round the year), the Mathabhanga and Sitai surface soils showed a higher value of non-exchangeable K [4.99 and $4.46 \mathrm{cmol}^{+} \mathrm{kg}^{-1}$, respectively] which in turn expected more $\mathrm{K}$ release under stress situation than the other soil samples (Sarkar et al., 2013).

The percent contribution of $\mathrm{K}_{\text {nex }}$ was much higher than the $\mathrm{K}_{\mathrm{ws}}$ and $\mathrm{K}_{\mathrm{ex}}$ towards total potassium in soil. The non-exchangeable $\mathrm{K}$ also showed positive correlation with the clay content of soil $\left(r=0.693^{* *}\right)$ implying the reserve of $\mathrm{K}$ on the clay surfaces. $\mathrm{K}_{\mathrm{nex}}$ also exhibited significantly positive correlation with $\mathrm{K}_{\mathrm{ws}}\left(\mathrm{r}=0.590^{*}\right), \mathrm{K}_{\mathrm{ex}}(\mathrm{r}=0.732 * *), \mathrm{K}_{\mathrm{s}}(\mathrm{r}=$ $\left.0.817^{* *}\right)$ and $\mathrm{K}_{\mathrm{t}}\left(\mathrm{r}=0.837^{* *}\right)$ indicating that $\mathrm{K}_{\text {nex }}$ at the time of analysis was likely to be present at equilibrium level with other forms of $\mathrm{K}$ as earlier report by (Amiri and Dorudi, 1994). The variability of $K_{n e x}$ in these soils could be predicted by $84.72 \%$ taking all the factors under consideration.

The structural $\mathrm{K}\left(\mathrm{K}_{\mathrm{s}}\right)$ in these soils were very high, ranged between 37.47 to $66.23 \mathrm{cmol}^{+} \mathrm{kg}^{-}$ 1 which is equivalent to $91.57-94.24 \%$ loading of total $\mathrm{K} . \mathrm{K}_{\mathrm{s}}$ also exhibited significantly positive correlation with organic carbon $\left(\mathrm{r}=0.903^{* *}\right)$, clay $\left(\mathrm{r}=0.713^{* *}\right)$ and CEC $(r=0.797 * *)$. Similar result was also obtained by Parkar et al., (1989). The stepdown multiple regression analysis (Table 4) indicate that the predictability of structural $\mathrm{K}$ could be explained more by adding silt and clay $\left(\mathrm{R}^{2} \times 100=85.24\right)$ and silt only $\left(\mathrm{R}^{2} \times\right.$ $100=73.51$ ) over the $\mathrm{pH}, \mathrm{EC}$, organic carbon and sand content $\left(\mathrm{R}^{2} \times 100=69.51\right)$ taken together. Such finding indicates presence of substantial quantities of K-bearing minerals (Singh et al., 1998). This result is further supported by the positive correlation $(\mathrm{r}=$ 0.551) of structural K with silt fraction of soil texture.

Table.1 Important physico-chemical properties of soils

\begin{tabular}{|c|c|c|c|c|}
\hline \multirow[t]{2}{*}{ Parameter } & \multicolumn{2}{|c|}{ Surface (0-20) soil } & \multicolumn{2}{|c|}{ Sub-surface (20-40) soil } \\
\hline & Range & Mean & Range & Mean \\
\hline pH (1:2.5) & $5.49-6.38$ & 5.85 & $5.58-6.49$ & 5.93 \\
\hline $\operatorname{EC}\left(\mathrm{dSm}^{-1}\right)(1: 2.5)$ & $0.05-0.08$ & 0.07 & $0.034-0.07$ & 0.051 \\
\hline Organic Carbon (\%) & $0.62-0.87$ & 0.75 & $0.384-0.06$ & 0.248 \\
\hline $\mathrm{CEC}\left(\mathrm{cmol}^{(+)} \mathrm{kg}^{-1}\right)$ & $5.13-6.5$ & 5.86 & $2.05-4.03$ & 3.15 \\
\hline Sand $(\%)$ & $63.1-57.2$ & 61.4 & $73.6-68.30$ & 70.38 \\
\hline Silt $(\%)$ & $16.7-25.1$ & 20.26 & $14.8-20.3$ & 17.45 \\
\hline Clay (\%) & $16.5-21.8$ & 18.33 & $10.3-13.9$ & 12.05 \\
\hline Texture & \multicolumn{2}{|c|}{ Sandy loam } & \multicolumn{2}{|c|}{ Sandy loam } \\
\hline
\end{tabular}


Table.2 Distribution of different forms of potassium in soils

\begin{tabular}{|c|c|c|c|c|c|c|c|}
\hline \multicolumn{2}{|c|}{ Soil Samples } & \multicolumn{6}{|c|}{ Potassium $\left[\mathrm{cmol}\left(\mathrm{p}^{+}\right) \mathrm{kg}^{-1}\right]$} \\
\hline Location & $\begin{array}{c}\text { Depth } \\
\text { (cm) }\end{array}$ & $\begin{array}{c}\text { Water } \\
\text { soluble } \\
\text { K }\end{array}$ & $\begin{array}{c}\text { Exchangeable } \\
\mathbf{K}\end{array}$ & $\begin{array}{c}\text { Available } \\
\text { K }\end{array}$ & $\begin{array}{c}\text { Non- } \\
\text { exchangeable } \\
\text { K }\end{array}$ & $\begin{array}{c}\text { Structural } \\
\mathbf{K}^{*}\end{array}$ & $\begin{array}{c}\text { Total } \\
\mathbf{K}\end{array}$ \\
\hline \multirow[t]{2}{*}{ Dhuluabari } & $0-20$ & $\begin{array}{c}0.107 \\
(0.183)\end{array}$ & $\begin{array}{c}0.226 \\
(0.386)\end{array}$ & $\begin{array}{c}0.333 \\
(0.569)\end{array}$ & $\begin{array}{c}3.98 \\
(6.81)\end{array}$ & $\begin{array}{c}54.17 \\
(92.63)\end{array}$ & 58.48 \\
\hline & $20-40$ & $\begin{array}{c}0.066 \\
(0.205)\end{array}$ & $\begin{array}{c}0.149 \\
(0.462)\end{array}$ & $\begin{array}{c}0.215 \\
(0.667)\end{array}$ & $\begin{array}{c}2.03 \\
(6.30)\end{array}$ & $\begin{array}{c}29.99 \\
(93.05)\end{array}$ & 32.23 \\
\hline \multirow[t]{2}{*}{ Pundibari } & $0-20$ & $\begin{array}{c}0.104 \\
(0.164)\end{array}$ & $\begin{array}{c}0.277 \\
(0.438)\end{array}$ & $\begin{array}{c}0.381 \\
(0.602)\end{array}$ & $\begin{array}{c}4.11 \\
(7.89)\end{array}$ & $\begin{array}{c}57.87 \\
(91.51)\end{array}$ & 63.24 \\
\hline & $20-40$ & $\begin{array}{c}0.060 \\
(0.127)\end{array}$ & $\begin{array}{c}0.106 \\
(0.224)\end{array}$ & $\begin{array}{c}0.166 \\
(0.351)\end{array}$ & $\begin{array}{c}3.39 \\
(7.17)\end{array}$ & $\begin{array}{c}43.72 \\
(92.47)\end{array}$ & 47.28 \\
\hline \multirow[t]{2}{*}{ Toofanganj } & $0-20$ & $\begin{array}{c}0.084 \\
(0.146)\end{array}$ & $\begin{array}{c}0.446 \\
(0.777)\end{array}$ & $\begin{array}{c}0.53 \\
(0.923)\end{array}$ & $\begin{array}{c}4.01 \\
(6.98)\end{array}$ & $\begin{array}{c}53.17 \\
(92.61)\end{array}$ & 57.41 \\
\hline & $20-40$ & $\begin{array}{c}0.066 \\
(0.155)\end{array}$ & $\begin{array}{c}0.138 \\
(0.325)\end{array}$ & $\begin{array}{c}0.204 \\
(0.480)\end{array}$ & $\begin{array}{c}2.24 \\
(5.27)\end{array}$ & $\begin{array}{l}40.08 \\
(94.26)\end{array}$ & 42.52 \\
\hline \multirow[t]{2}{*}{ Mathabhanga } & $0-20$ & $\begin{array}{c}0.087 \\
(0.138)\end{array}$ & $\begin{array}{c}0.401 \\
(0.637)\end{array}$ & $\begin{array}{c}0.488 \\
(0.775)\end{array}$ & $\begin{array}{c}4.99 \\
(7.93)\end{array}$ & $\begin{array}{c}58.33 \\
(92.69)\end{array}$ & 62.93 \\
\hline & $20-40$ & $\begin{array}{c}0.069 \\
(0.200)\end{array}$ & $\begin{array}{c}0.167 \\
(0.483)\end{array}$ & $\begin{array}{c}0.236 \\
(0.683)\end{array}$ & $\begin{array}{c}3.21 \\
(9.29)\end{array}$ & $\begin{array}{c}31.09 \\
(90.01)\end{array}$ & 34.54 \\
\hline \multirow[t]{2}{*}{ Dinhata } & $0-20$ & $\begin{array}{c}0.109 \\
(0.089)\end{array}$ & $\begin{array}{c}0.193 \\
(0.273)\end{array}$ & $\begin{array}{c}0.302 \\
(0.428)\end{array}$ & $\begin{array}{c}4.08 \\
(5.78)\end{array}$ & $\begin{array}{c}66.23 \\
(93.80)\end{array}$ & 70.61 \\
\hline & $20-40$ & $\begin{array}{c}0.046 \\
(0.154)\end{array}$ & $\begin{array}{c}0.156 \\
(0.303)\end{array}$ & $\begin{array}{c}0.202 \\
(0.392)\end{array}$ & $\begin{array}{c}2.77 \\
(5.37)\end{array}$ & $\begin{array}{l}48.60 \\
(94.24)\end{array}$ & 51.57 \\
\hline \multirow[t]{2}{*}{ Sitai } & $0-20$ & $\begin{array}{c}0.063 \\
(0.099)\end{array}$ & $\begin{array}{c}0.368 \\
(0.579)\end{array}$ & $\begin{array}{c}0.431 \\
(0.678)\end{array}$ & $\begin{array}{c}4.46 \\
(7.02)\end{array}$ & $\begin{array}{c}58.66 \\
(92.31)\end{array}$ & 63.55 \\
\hline & $20-40$ & $\begin{array}{c}0.037 \\
(0.091)\end{array}$ & $\begin{array}{c}0.228 \\
(0.563)\end{array}$ & $\begin{array}{l}0.265 \\
(0.654)\end{array}$ & $\begin{array}{c}2.79 \\
(6.89)\end{array}$ & $\begin{array}{c}37.47 \\
(92.47)\end{array}$ & 40.52 \\
\hline
\end{tabular}

*Calculated by subtracting the sum of water soluble K, exchangeable $\mathrm{K}$ and Non-exchangeable $\mathrm{K}$ from the total $\mathrm{K}$

** Figure in parenthesis denote the percent loading of each forms of $\mathrm{K}$ with respect to total $\mathrm{K}$ in present soils 
Table.3 Pearson correlation-coefficient of different forms of potassium with soil properties

\begin{tabular}{|c|c|c|c|c|c|c|}
\hline & $\begin{array}{c}\text { Water } \\
\text { soluble K }\end{array}$ & $\begin{array}{c}\text { Exchangeable } \\
\text { K }\end{array}$ & $\begin{array}{c}\text { Non- } \\
\text { exchangeable } \mathrm{K}\end{array}$ & $\begin{array}{c}\text { Available } \\
\mathbf{K}\end{array}$ & $\begin{array}{c}\text { Structural } \\
\mathbf{K} *\end{array}$ & Total K \\
\hline pH & 0.232 & -0.245 & -0.043 & -0.181 & -0.246 & -0.240 \\
\hline EC & 0.439 & 0.432 & 0.419 & 0.486 & 0.369 & 0.380 \\
\hline Organic carbon & $0.680^{*}$ & $0.682 *$ & $0.834 * *$ & $0.764 * *$ & $0.903 * *$ & $0.914 * *$ \\
\hline Sand & -0.574 & $-0.735 * *$ & $-0.814 * *$ & $-0.793 * *$ & $-0.796 * *$ & $-0.809 * *$ \\
\hline Silt & 0.190 & 0.376 & $0.608 *$ & 0.386 & 0.551 & 0.565 \\
\hline Clay & $0.687 *$ & $0.745 * *$ & $0.693 * *$ & $0.824 * *$ & $0.713 * *$ & $0.722 * *$ \\
\hline CEC & $0.694 *$ & $0.656^{*}$ & $0.808 * *$ & $0.742 * *$ & $0.797 * *$ & $0.807 * *$ \\
\hline Water soluble K & - & 0.288 & $0.590 *$ & 0.462 & $0.634 *$ & $0.644 *$ \\
\hline Exchangeable K & - & - & $0.732 * *$ & $0.982 * *$ & 0.544 & 0.560 \\
\hline Available K & & & $0.793 * *$ & $1 * *$ & $0.627 *$ & $0.644 *$ \\
\hline Non-exchangeable K & - & - & - & $0.793 * *$ & $0.817 * *$ & $0.837 * *$ \\
\hline Structural K* & - & - & - & & - & $0.999 * *$ \\
\hline Total K & - & - & - & & - & - \\
\hline
\end{tabular}

$*$ and $* *$ indicate that correlation coefficients are significant at $\mathrm{P}<0.05$ and $\mathrm{P}<0.01$, respectively

Table.4 Multiple regression equations relating extractability of different forms of potassium with soil properties

\begin{tabular}{|l|c|}
\hline \multicolumn{1}{|c|}{$\begin{array}{c}\text { Step-down regression equations } \\
\text { Water soluble K }\end{array}$} & $\mathbf{R}^{2} \times \mathbf{1 0 0}$ \\
\hline \multicolumn{1}{|c|}{$\quad$} & \\
\hline $\mathrm{Y}=-2.60+0.012 \mathrm{X}_{1}+0.245 \mathrm{X}_{2}+0.07 \mathrm{X}_{3}+0.027 \mathrm{X}_{4}+0.020 \mathrm{X}_{5}+0.023 \mathrm{X}_{6}+0.013 \mathrm{X}_{7}$ & 86.58 \\
\hline $\mathrm{Y}=-2.07+0.025 \mathrm{X}_{1}+0.190 \mathrm{X}_{2}+0.088 \mathrm{X}_{3}+0.020 \mathrm{X}_{4}+0.016 \mathrm{X}_{5}+0.020 \mathrm{X}_{6}$ & 83.78 \\
\hline $\mathrm{Y}=-0.152+0.033 \mathrm{X}_{1}+0.173 \mathrm{X}_{2}+0.098 \mathrm{X}_{3}+0.0005 \mathrm{X}_{4}-0.003 \mathrm{X}_{5}$ & 82.41 \\
\hline $\mathrm{Y}=-0.326+0.034 \mathrm{X}_{1}+0.145 \mathrm{X}_{2}+0.102 \mathrm{X}_{3}+0.002 \mathrm{X}_{4}$ & 74.54 \\
\hline $\mathrm{Y}=-0.146+0.032 \mathrm{X}_{1}-0.120 \mathrm{X}_{2}+0.076 \mathrm{X}_{3}$ & 71.01 \\
\hline $\mathrm{Y}=-0.013+0.008 \mathrm{X}_{1}-0.619 \mathrm{X}_{2}$ & 21.38 \\
\hline Exchangeable $\mathrm{K}$ & \\
\hline $\mathrm{Y}=6.41+0.013 \mathrm{X}_{1}-0.682 \mathrm{X}_{2}+0.090 \mathrm{X}_{3}-0.069 \mathrm{X}_{4}-0.048 \mathrm{X}_{5}+0.034 \mathrm{X}_{6}-0.054 \mathrm{X}_{7}$ & 65.62 \\
\hline $\mathrm{Y}=4.27-0.040 \mathrm{X}_{1}-0.441 \mathrm{X}_{2}+0.021 \mathrm{X}_{3}-0.043 \mathrm{X}_{4}-0.034 \mathrm{X}_{5}+0.021 \mathrm{X}_{6}$ & 63.58 \\
\hline $\mathrm{Y}=2.24-0.048 \mathrm{X}_{1}-0.428 \mathrm{X}_{2}+0.010 \mathrm{X}_{3}-0.022 \mathrm{X}_{4}-0.014 \mathrm{X}_{5}$ & 52.52 \\
\hline $\mathrm{Y}=1.56-0.043 \mathrm{X}_{1}-0.537 \mathrm{X}_{2}+0.026 \mathrm{X}_{3}-0.026 \mathrm{X}_{4}$ & 52.17 \\
\hline $\mathrm{Y}=0.194-0.026 \mathrm{X}_{1}+1.46 \mathrm{X}_{2}+0.222 \mathrm{X}_{3}$ & 49.22 \\
\hline $\mathrm{Y}=0.586-0.096 \mathrm{X}_{1}+3.62 \mathrm{X}_{2}$ & 30.34 \\
\hline $\mathrm{A} v a i l a b l e \mathrm{~K}$ & \\
\hline $\mathrm{Y}=3.81+0.025 \mathrm{X}_{1}-0.437 \mathrm{X}_{2}+0.160 \mathrm{X}_{3}-0.042 \mathrm{X}_{4}+0.028 \mathrm{X}_{5}-0.011 \mathrm{X}_{6}-0.040 \mathrm{X}_{7}$ & 75.07 \\
\hline $\mathrm{Y}=2.20-0.014 \mathrm{X}_{1}-0.255 \mathrm{X}_{2}+0.108 \mathrm{X}_{3}-0.022 \mathrm{X}_{4}-0.018 \mathrm{X}_{5}+0.001 \mathrm{X}_{6}$ & 74.06 \\
\hline $\mathrm{Y}=2.09-0.015 \mathrm{X}_{1}-0.255 \mathrm{X}_{2}+0.107 \mathrm{X}_{3}-0.021 \mathrm{X}_{4}-0.017 \mathrm{X}_{5}$ & 68.07 \\
\hline $\mathrm{Y}=1.23-0.008 \mathrm{X}_{1}-0.392 \mathrm{X}_{2}+0.128 \mathrm{X}_{3}-0.001 \mathrm{X}_{4}$ & 66.85 \\
\hline $\mathrm{Y}=0.479+0.005 \mathrm{X}_{1}+1.345 \mathrm{X}_{2}+0.298 \mathrm{X}_{3}$ & 61.04 \\
\hline $\mathrm{Y}=0.573-0.087 \mathrm{X}_{1}+4.24 \mathrm{X}_{2}$ & 31.92 \\
\hline
\end{tabular}




\begin{tabular}{|l|l|}
\hline Non-exchangeable $\mathrm{K}$ & \\
\hline$Y=113.89+1.318 \mathrm{X}_{1}-18.389 \mathrm{X}_{2}+3.007 \mathrm{X}_{3}-1.229 \mathrm{X}_{4}-1.034 \mathrm{X}_{5}-1.086 \mathrm{X}_{6}-0.331 \mathrm{X}_{7}$ & 84.72 \\
\hline$Y=100.69+0.989 \mathrm{X}_{1}-16.902 \mathrm{X}_{2}+2.578 \mathrm{X}_{3}-1.064 \mathrm{X}_{4}-0.949 \mathrm{X}_{5}-1.004 \mathrm{X}_{6}$ & 83.56 \\
\hline$Y=4.54+0.602 \mathrm{X}_{1}-16.252 \mathrm{X}_{2}+2.073 \mathrm{X}_{3}-0.079 \mathrm{X}_{4}+0.029 \mathrm{X}_{5}$ & 81.29 \\
\hline$Y=6.02+0.590 \mathrm{X}_{1}-16.018 \mathrm{X}_{2}+2.038 \mathrm{X}_{3}-0.092 \mathrm{X}_{4}$ & 80.92 \\
\hline$Y=-1.85+0.687 \mathrm{X}_{1}-4.45 \mathrm{X}_{2}+3.172 \mathrm{X}_{3}$ & 76.47 \\
\hline$Y=-3.72-0.307 \mathrm{X}_{1}+26.337 \mathrm{X}_{2}$ & 19.35 \\
\hline Structural K & 86.19 \\
\hline$Y=-769.839-4.365 \mathrm{X}_{1}-144.255 \mathrm{X}_{2}+22.609 \mathrm{X}_{3}+8.286 \mathrm{X}_{4}+8.086 \mathrm{X}_{5}+8.254 \mathrm{X}_{6}+3.843$ & \\
\hline$X_{7}$ & 85.24 \\
\hline$Y=-616.737-0.547 \mathrm{X}_{1}-161.5 \mathrm{X}_{2}+25.577 \mathrm{X}_{3}+6.365 \mathrm{X}_{4}+7.102 \mathrm{X}_{5}+7.296 \mathrm{X}_{6}$ & 73.51 \\
\hline$Y=81.969+2.268 \mathrm{X}_{1}-166.211 \mathrm{X}_{2}+31.251 \mathrm{X}_{3}-0.794 \mathrm{X}_{4}-0.014 \mathrm{X}_{5}$ & 69.51 \\
\hline$Y=81.240+2.274 \mathrm{X}_{1}-166.337 \mathrm{X}_{2}+31.269 \mathrm{X}_{3}-0.787 \mathrm{X}_{4}$ & 68.54 \\
\hline$Y=13.595+3.102 \mathrm{X}_{1}-67.038 \mathrm{X}_{2}+41.008 \mathrm{X}_{3}$ & 24.46 \\
\hline$Y=85.746-9.745 \mathrm{X}_{1}+331.104 \mathrm{X}_{2}$ & \\
\hline
\end{tabular}

$\mathrm{X}_{1}=\mathrm{pH}, \mathrm{X}_{2}=\mathrm{EC}, \mathrm{X}_{3}=$ Organic carbon, $\mathrm{X}_{4}=$ Sand, $\mathrm{X}_{5}=$ Silt, $\mathrm{X}_{6}=$ Clay, $\mathrm{X}_{7}=\mathrm{CEC}$

In general, the soils are rich in total $\mathrm{K}\left(\mathrm{K}_{\mathrm{t}}\right)$ content ranging from 32.23- $70.61 \mathrm{cmol}^{+} \mathrm{kg}^{-1}$. The surface soil exhibited relatively more $\mathrm{K}_{\mathrm{t}}$ content than the sub-surface soil. This might be due to the less leaching of potassium from surface soil thereby indicating higher rate of fixation of potassium by the clay and organic matter present more in the surface zone of soil. This further supported by the highly significant positive correlation of $\mathrm{K}_{\mathrm{t}}$ with organic carbon $\left(\mathrm{r}=0.914^{* *}\right)$ and clay content $\left(\mathrm{r}=0.722^{* *}\right)$ of soil. $\mathrm{K}_{\mathrm{t}}$ was significantly and negatively correlated with sand $(-0.809 * *)$.

This is because of the presence of quartz, which makes up half of the sand fraction and does not retain K (Deka et al., 1995).

The total $\mathrm{K}$ had mostly significant positive correlation with all the other forms of potassium establishing dynamic relationship of different forms of potassium in soil (Reza et al., 2014).

The results obtained from the present investigation thus, revealed that there was not much variation among the different forms of potassium in soils of different blocks of Cooch Behar. However, the distribution of these different $\mathrm{K}$ forms is greatly influenced by soil properties and also by the inter-relationship amongst themselves. Organic carbon, clay and CEC played most important role to predict the variability of different forms of potassium.

\section{References}

Amiri, R. and Dorudi, M.S. 199. Potassium forms and clay mineralogy of some paddy soils in Northern Iran. $J$. Potassium Res. 10(1): 1-11.

Askegaard, M., Eriksen, J. and Olesen. J.E. (2003) Exchangeable potassium and potassium balances in organic crop rotations on coarse sand. Soil Use Manage. 19(1): 96-103.

Bashir U, Ali T, Qureshi F. 2016. Distribution of different forms of potassium under temperature conditions of Kashmir. In. J. Ag. Env. Biotech. 9(2): 213-219.

Basumatary, A. and Bordoloi, P.K. 1992. Forms of potassium in soils of Assam in relation to soil properties. J. Indian Soc. Soil Sci. 40(4): 443-446.

Bray, R.H. 1948. Requirements for successful soil tests. Soil Sci. 66(1), 83-89.

Deka, B., Sawhney, J.S. and Mukhopadhyay, S.S. 1995. Clay mineralogy as influenced by landforms in Siwalik Himalayas. Clay Res. 14(1): 16-21.

Dhillon, S.K., Sidhu, P.S., Dhillon, K.S. and 
Sharma, Y.P. 1985. Distribution of various potassium forms in some benchmark soils of North West India. $J$. Potassium Res. 1(1): 154-165.

Grewal, J.S. and Kanwar, J.S. 1966. Forms of potassium in Punjab soils. J. Indian Soc. Soil Sci. 14(1): 63-67.

Jackson, M.L. 1973. Soil Chemical Analysis. Prentice Hall of India Pvt. Ltd, New Delhi.

Lalitha, M. and Dhakshinamoorthy, M. 2014. Forms of Soil potassium- A Review. Agricultural Reviews, 35(1): 64-68.

Parker, D.R., Hendricks, G.J. and Spark, D.L. 1989. Potassium in Atlantic Coastal Plain Soils, I. Soil characterization and distribution of potassium. Soil Sci. Soc. Am. J. 53(2): 392-396.

Pavlov, K.V. 2007. The assessment of the potassium status of soil by the proportion between different forms of potassium. Eur. J. Soil Sci. 40(7): 792794.

Pratt, P.F. 1965. Digestion with hydrofluoric and perchloric acids for total potassium and sodium. In: Methods of Soil Analysis, Part 2 (Eds) C. A. Black et al., Madison, Wisconsin. American Society of Agronomy. Pp. 1019-1020.

Ramamoorthy, B. and Paliwal, K.V. 1976. Potassium adsorption ratio for some paddy soils in relation to their potassium availability. Soil Sci. 99: 236-242.

Rao, A.S. and Brar, M.S. 2002. Potassium. In: Fundamentals in Soil Science. Soil Science Society of India, New Delhi, India. Pp. 369-380.

Reza, S.K., Baruah, U., Dutta, D., Sarkar, D. and Dutta, D.P. (2014) Distribution of forms of potassium in Lesser Himalayas of Sikkim, India. Agropedology, 24(1): 106-110.
Saini, J. and Grewal, K.S. 2014. Vertical distribution of different forms of potassium and their relationship with different soil properties in some Haryana soils under different crop rotation. $A d v$. Plants Ag. Res., 1(2): 48-52.

Sanyal, S. K. 2001. Potassium availability of soils of West Bengal in relation to their mineralogy. In: Use of Potassium in West Bengal Agriculture. Department of Agriculture, Government of West Bengal, Potash and Phosphate Institute of Canada (India programme), Kolkata. Pp. 41-54.

Sarkar, G.K, Debnath, A. Chattopadhyay, A.P. and Sanyal, S.K. 2013. Depletion of Soil Potassium under Exhaustive Cropping in Inceptisol and Alfisol. Communications in Soil Science and Plant Analysis, 45(1): 61-72.

Singh, O.P. and Datta, B. 1986. Forms of potassium in some soils of Mizoram. $J$. Indian Soc. Soil Sci. 34(2): 187-190.

Singh, K. and Tripathi, D. 1993. Different forms of potassium and their distribution in some representative soil groups of Himachal Pradesh. J. Potassium Res. 9:196-205.

Singh, S.P., Ram, J., Singh, N. and Haldar, A.K. 1998. Forms of Potassium in some soils of Arunachal Pradesh. Agropedology, 8(1): 90-93.

Sparks DL. 2000. Bioavailability of soil potassium. In: Handbook of Soil Science (Eds.) M.E. Sumner. CRC Press, Boca Raton, FL. Pp. D-38-D-52.

Tijjani, M.A. and David, A.A. 2017. Forms and Distribution of Potassium along a Toposequence on Basaltic Soils of Vom, Jos Plateau State of Nigeria. In. J. Env. Ag. Biotech. 2(1): 213-218.

\section{How to cite this article:}

Singh, N.K., G.C. Banik and Mukhopadhyay, D. 2019. Distribution of Different Forms of Potassium in Relation to Soil Properties in Agricultural Entisols of Terai Region of West Bengal, India. Int.J.Curr.Microbiol.App.Sci. 8(12): 860-868.

doi: https://doi.org/10.20546/ijcmas.2019.812.110 